\title{
Utilization of Financial Resources for Sustainable Development by Micro, Small and Medium Agricultural Enterprises in Enugu State, Nigeria
}

\author{
L.U. Ekenta, F.M. Onu, F.N. Ezebuiro, M.E. Ikehi, B.A. Omeje \\ Department of Agricultural Education \\ University of Nigeria, Nsukka \\ N.F. Ibekwe \\ Department of Agricultural Education \\ Enugu State College of Education Technical
}

\begin{abstract}
The study investigated the utilization of financial resources for sustainable development by micro, small and medium agricultural enterprises in Enugu State, Nigeria. Two research questions and two null hypotheses guided the study. The study adopted descriptive survey research design. The population for the study was 243 made up of 162 micro, 79 small and 2 medium entrepreneurs in the study area. The entire population was studied due to manageable size of the population. The instrument for data collection was 21 -item structured questionnaire. Cronbach alpha method was used to determine the internal consistency of the items and an overall reliability coefficient of 0.81 was obtained. The data collected were analyzed using weighted mean to answer the research questions while ANOVA statistic was used to test the null hypotheses at the probability level of 0.05. The findings revealed that lease holding, owner's capital, issue of shares, and capital support and subsidies from government are some of the sources of financial resources for sustainable development by micro, small and medium agricultural enterprises. The findings also showed that allocation based on needs, allocation of funds based on budgets and budgeting, proportional allocation of funds to both fixed and current assets, and judicious allocation of funds based on budget procedure determined funds were utilized by entrepreneurs in micro, small and medium agricultural enterprises. The study also found that there was no significant difference $(p>0.05)$ in the mean ratings of micro, small and medium agricultural entrepreneurs on the hypotheses tested. It was recommended that micro, small and medium agricultural entrepreneurs in Enugu State should make effort to adopt the identified strategies in order to ensure efficient utilization of financial resources in their enterprises. Educational institutions should use these findings to teach students on sources of financial resources and how these financial resources should be utilized as financial tools for successes of the enterprise.
\end{abstract}

Keywords: utilization, financial resources, micro, small and medium enterprises, sustainable development

\section{Introduction}

There is no meaningful development in a developing country without the agricultural sector. For Nigerian economy to be stable, and prosperous, priority must be given to agricultural enterprises. An agricultural enterprise is the production, processing and marketing of agricultural products (Fuchs, 2010). The author further stated that agricultural enterprise is principally concerned with plant and animal production and other farm activities and practices performed by a farmer. Agricultural enterprise provides food for the increasing population, adequate raw materials to growing industrial sector; a major source of employment; generation of foreign exchange earnings; and market for the products of the industrial sector (Nchukwuwe and Adejuwon, 2012).

Agricultural enterprises are grouped into micro, small and medium. Small and Medium Enterprises Development Agency of Nigeria (2015) noted that the significance of micro, small and medium enterprises (MSMEs) for the growth, productivity and competitiveness of the economics of developing countries is universally recognized. Micro, small and medium enterprises is of critical breeding and nurturing grounds for domestic entrepreneurial capacities, technical skills, technological innovativeness and managerial competencies for private sector. Micro, small and medium enterprises (MSMEs) are the backbone of any economy thus when government or international institutions put forward a plan or policy, they show great concern on the role of MSMEs as these businesses are crucial to economic growth and development. These enterprises make use of financial resource. Vitez (2013) defined financial resources as funds for starting or continuing business operations. Financial resources therefore mean cash or credit available to agricultural enterprise for starting and running the business. Financial resources are the purchasing power of an enterprise. The purchasing power could be in form of cash or credit. 
In Enugu State, it has been noted from literature that micro, small and medium agricultural enterprises are not growing in spite of the efforts put by the government and stakeholders for their progress. Micro, small and medium agricultural enterprises in the State are not growing as expected in terms of increase in food production, poverty alleviation, employment generation, increased expansion rate, high rate of agricultural enterprise development among others. Ozor and Nnaji (2010) noted that over 75\% of agricultural production takes place in rural areas where more than $80 \%$ are engaged in farming activities. It is expected that there should be varieties of food in the market. However, as a result of low productivity in the State, foods are being imported from other States of Nigeria. Many people switch from one business to another, or close their shops because of low profit. Entrepreneurs in the State have problems of sourcing funds from banks for their businesses because some lack access to credit, collateral and also high interest rate charged by banks. Many enterprises in the State are faced with financial problems; namely inability to obtain external financing, inability to obtain internal financing, insufficient capital, among others. This prevents the enterprise from carrying out their financial obligations. Some entrepreneurs find it difficult to employ financial managers who have the skills to manage the financial records of the enterprises while others who are inexperienced handle the financial records of the enterprises by themselves resulting to inappropriate financial resources management practices. Onyemenam (2013) noted that financial problems of small business in Enugu State include: inadequate planning, poor accounting and record keeping, management incompetence and financial indiscipline. These problems prevent the enterprise from achieving sustainable development. Sustainable development, according to Turner (2014), is the fulfillment of human needs with the protection of the natural environment.

Agricultural enterprises cannot sustainable their development without proper utilization of financial resources. It is against this background that the study sought to investigate utilization of financial resources for sustainable development by micro, small and medium agricultural enterprises in Enugu State, Nigeria.

\section{Purpose of the Study}

The major purpose of the study was to investigate utilization of financial resources for sustainable development by micro, small and medium agricultural enterprises in Enugu State. Specifically, the study sought to;

1. Identify sources of financial resources for sustainable development by micro, small and medium agricultural enterprises in Enugu State.

2. Determine how financial resources are utilized by entrepreneurs for sustainable development by micro, small and medium agricultural enterprises in Enugu State.

\section{Research Questions}

The study was guided by the following research questions:

1. What are the sources of financial resources for sustainable development by micro, small and medium agricultural enterprises in Enugu State, Nigeria?

2. How are financial resources utilized by entrepreneurs for sustainable development by micro, small and medium agricultural enterprises in Enugu State, Nigeria?

\section{Hypotheses}

The following null hypotheses were tested at 0.05 probability level.

$\mathbf{H O}_{1:}$ There is no significant difference in the mean ratings of sources of financial resources for sustainable development by micro, small and medium agricultural enterprises in Enugu State.

$\mathbf{H O}_{2}$ : There is no significant difference in the mean ratings of how financial resources were utilized by entrepreneurs for sustainable development by micro, small and medium agricultural enterprises in Enugu State.

\section{Methodology}

This study adopted descriptive survey, aimed at investigating utilization of financial resources for sustainable development by micro, small and medium agricultural enterprises in Enugu State, Nigeria. The population for the study was 243 entrepreneurs, made up of 162 micro, 79 small and 2 medium registered agricultural enterprises in Enugu State. 243 respondents who are entrepreneurs provided information for data used for the study. Specifically the population was obtained from groups of enterprises; Small and Medium Enterprises Development Agency of Nigeria, Enugu Branch (SMEDAN) with 39 entrepreneurs, Poultry Association of Nigeria(PAN) Enugu Branch with 26, Fadama 90 entrepreneurs, and Enugu State Commercial Agriculture Development Project (CADP) World Bank Assisted with 88 entrepreneurs. (Source: Small and Medium Enterprises Development Agency of Nigeria (SMEDAN) Enugu Branch, Poultry Association of Nigeria (PAN), Enugu Branch, FADAMA and Enugu State Commercial Agriculture Development Project (CADP) World Bank Assisted 2015). The entire population of 243 entrepreneurs was studied due to the manageable size of the population. 
Therefore, there was no sampling. The instrument for data collection was a structured questionnaire developed from the literature by the researcher titled "Utilization of financial resources questionnaire" (UFRQ).

A twenty-one (21) item survey instrument was structured on a four point scale with response options of Strongly Agree (SA), Agree (A), Disagree (D), and Strongly Disagree (SD) with corresponding values as 4, 3, 2 and 1 respectively. The instrument was face-validated by three experts: two from the Department of Agricultural Education, University of Nigeria, Nsukka and one from Department of Technology and Vocational Education, Enugu State University of Science and Technology, Enugu. The comments and corrections made by validates were integrated and used to modify the final draft of the instrument. The validated instrument was trial tested on 15 respondents of agricultural enterprises in Anambra State that posses similar characteristics with the study area. The aim was to determine the reliability of the instrument using Cronbach alpha method which yielded a coefficient of 0.81.Data was collected by the researcher with the help of three research assistants who were instructed on how to distribute the instrument for collection of data. Data collected were analyzed using weighted mean to answer the research questions and Analysis of Variance Statistic (ANOVA) to test the null hypotheses with the help of statistical package for social sciences (SPSS) version 21. Standard deviation was used to determine the closeness of the respondents to the mean and to each other in their responses.

\section{Presentation and Analysis of Results}

\section{Research Questions 1:}

1. What are the sources of financial resources for sustainable development by micro, small and medium agricultural enterprises in Enugu State, Nigeria?

\section{Table 1: Mean ratings and standard deviations on sources of financial resources for sustainable development by} micro, small and medium agricultural enterprises.

\begin{tabular}{llcll}
\hline S/No & Items & $\overline{\boldsymbol{X}}$ & SD & Remarks \\
\hline 1 & Lease holding & 2.91 & 0.95 & Agree \\
2 & Long term loans & 2.92 & 0.93 & Agree \\
3 & Short term overdraft & 2.53 & 0.81 & Agree \\
4 & Owners' capital & 3.45 & 0.84 & Agree \\
5 & Issue of shares & 2.64 & 0.95 & Agree \\
6 & Debentures & 2.43 & 0.85 & Disagree \\
7 & Credit purchases & 2.90 & 0.79 & Agree \\
8 & Partnership & 3.21 & 0.86 & Agree \\
9 & Venture capital & 2.63 & 0.90 & Agree \\
10 & Franchising & 2.58 & 0.84 & S.Agree \\
11 & Capital support and subsidies from government & 3.13 & 0.95 & Agree \\
12 & Hire purchase & 3.02 & 0.83 & Agree \\
& Grand mean & 2.86 & 0.87 & Agree \\
\hline
\end{tabular}

Data presented in Table 1 revealed that 11 out of the 12 items had their mean values ranging from 2.53 to 3.45 . Each of the mean values of the 11 items was above 2.50; indicating that the respondents agreed to the items as sources of financial resources for sustainable development by micro, small and medium agricultural in Enugu State. However, one of the 12 items had a mean value of 2.43. The value was below 2.50; indicating that the respondents did not agree to the items as sources of financial resources for sustainable development by micro, small and medium agricultural enterprises in Enugu State. The standard deviation of all the 12 items ranged from 0.79 - 0.95. Each of these values was less than 1.96 (95\% confidence level), indicating that the three groups of respondents (micro, small and medium enterprises) were close to the mean and to each other in their responses.

\section{Hypothesis One}

There is no significant difference $(\mathrm{P}>0.5)$ in the mean ratings of sources of financial resources for sustainable development by micro, small and medium agricultural enterprises in Enugu State. 
Table 2: Analysis of variance (ANOVA) of the mean responses of three groups of the respondents on sources of financial resources for sustainable development by micro, small and medium agricultural enterprises

\begin{tabular}{|c|c|c|c|c|c|}
\hline & Sum of Squares & Df & Mean Square & $\mathrm{F}$ & Sig. \\
\hline Between Groups & 19.1 & 2 & .095 & .956 & 0.39 \\
\hline Within Groups & 4.48 & 238 & .100 & & \\
\hline Total & 4.67 & 240 & & & \\
\hline
\end{tabular}

Data in Table 2 showed that the significant level was 0.39 . The value $(0.39)$ is greater than 0.05 , indicating that there was no significant difference in the mean ratings of the three groups of respondents on sources of funds utilized by micro, small and medium agricultural enterprises for sustainable development in Enugu State. The null hypothesis of no significant difference was, therefore, accepted.

\section{Research Question 2}

How are financial resources utilized by entrepreneurs for sustainable development by micro, small and medium agricultural enterprises in Enugu State, Nigeria?

Table 3: Mean ratings and standard deviations of respondents on how financial resources were utilized by entrepreneurs for sustainable development in micro, small and medium agricultural enterprises.

\begin{tabular}{llccc}
\hline SWN & Items & $\overline{\boldsymbol{X}}$ & SD & Remark \\
\hline 1 & Proportional allocation of funds to both fixed and & 2.91 & 0.78 & Agree \\
& current assets & 3.14 & 0.86 & Agree \\
2 & Allocation based on needs & 2.76 & 0.81 & Agree \\
3 & Allocating more funds to inventories & 2.61 & 0.74 & Agree \\
4 & Allocating more funds to fixed assets & 2.74 & 0.79 & Agree \\
5 & Investing more funds in working capital & 2.55 & 0.81 & Agree \\
6 & Equal allocation to all sections & 2.59 & 0.87 & Agree \\
7 & Allocating funds based on model & 3.21 & 0.84 & Agree \\
8 & Allocation of funds based on budgets and budgeting & 3.48 & 1.40 & Agree \\
9 & Budget procedure is followed for judicious allocation of funds & 2.88 & 0.87 & Agree \\
\hline
\end{tabular}

Data presented in Table 3 revealed that all the items had their mean values ranged from 2.55-3.48. Each of the mean values of the 9 items was above 2.50; indicating that the respondents agreed to all the items as how financial resources were utilized by entrepreneurs for sustainable development by micro, small and medium agricultural enterprises in Enugu State. The standard deviation of the 9 items ranged from 0.74- 1.40. These values were less than 1.96 (95\% confidence level); indicating that all the respondents were close to the mean and to each other in their responses.

\section{Hypothesis Two}

There is no significant difference in the mean ratings of how financial resources were utilized by entrepreneurs for sustainable development by micro, small and medium agricultural enterprises in Enugu State.

Table 4:

Analysis of variance (ANOVA) of the three groups of the respondents on how financial resources were utilized by micro, small and medium agricultural enterprises

\begin{tabular}{|c|c|c|c|c|}
\hline & \multicolumn{2}{|c|}{ Sum of Squares Df } & Mean Square F & Sig. \\
\hline Between Group & 11.29 & 2 & $\begin{array}{ll}5.64 & 1\end{array}$ & 1.940 .16 \\
\hline Within Groups & 95.94 & 238 & 2.91 & \\
\hline Total & 107.22 & 240 & & \\
\hline
\end{tabular}

Data in Table 4 showed that the significant level was 0.160 . This value $(0.160)$ is greater than 0.05 ; indicating that there was no significant difference in the mean ratings of the three groups of the respondents on how financial resources were utilized for sustainable development by micro, small and medium agricultural enterprises in Enugu State. The null hypothesis of no significant difference was, therefore, upheld. 


\section{Discussion}

The results obtained from table 1 revealed that lease holding, owners capital, issue of shares and capital and subsidies from government were some of the sources of financial resources for sustainable development by micro, small and medium agricultural enterprises. The findings were also in agreement with Kadam (2012) who revealed that business has many choices for getting additional funds and has to choose from the sources out of which are issues of shares and debentures, loans from banks and financial institutions, public deposits in form of bonds.

The findings were also in line with Ewiwile, Azu, and Owa (2011) who indicated that owners saving and savings from his or her associates including family and friends who may not be partner or shareholders in the venture, banks and leading institutions, small business administration and financial assistance programme were sources of financial resources for sustainable development by micro, small and medium agricultural enterprises. There was no significant difference in the mean ratings of the three groups of respondents on sources of financial resources for sustainable development by micro, small and medium in Enugu State. The null hypothesis of no significant difference was accepted. The implication of this finding was that the scale of business of each group did not influence their responses on sources of financial resources. The major findings on how financial resources were utilized by micro, small and medium agricultural enterprises revealed allocation based on needs, allocation of funds based on budgets and budgeting, proportional allocation of funds to both fixed and current assets, and budget procedure should be followed for judicious allocation of funds. The findings were in agreement with Shilpa and Rakesh (2013) who indicated that funds should be spent on fixed assets and then an appropriate portion will be retained for working capital. The authors also noted that while investing the amount on fixed assets, decision making techniques like capital budgeting; opportunity cost analysis etc may be applied and principles of safety, liquidity, profitability should be considered. There was no significant difference in the mean rating of the three groups of respondents on how financial resources were utilized for sustainable development by micro, small and medium agricultural enterprises in Enugu State. The null hypothesis of no significant difference was accepted. The implication of this finding was that business experiences of each group did not influence their responses on how financial resources were utilized.

\section{Conclusion}

The importance of micro, small and medium agricultural enterprises cannot be overemphasized due to their great contribution in national economy. Therefore, in order to achieve effective financial resources of the enterprise, there is need for proper sourcing and utilization of funds by micro, small and medium agricultural enterprises to achieve the set objectives. The study has therefore made the following contributions to knowledge in respect of achieving proper utilization of financial resources for sustainable development by micro, small and medium agricultural enterprises in Enugu State, Nigeria. The findings if properly applied by micro, small and medium agricultural enterprises would result in appropriate utilization of financial resources leading to increase in food production, maximization of profit, and creation of employment thereby alleviating poverty in Enugu State.

\section{Recommendations}

Based on the result of this study, the following recommendations were made:

1. Micro, small and medium agricultural entrepreneurs in Enugu State should make effort to adopt the identified strategies in order to ensure efficient utilization of financial resources in their enterprises.

2. Educational institutions should use these findings to teach students on sources of financial resources and how these financial resources should be utilized as financial tools for successes of the enterprise.

3 Extension services should use the findings to educate and disseminate information on sources of financial resources and its utilization to agricultural entrepreneurs in order to achieve sustainable development.

\section{References}

Akinsulire, O. (2002). Financial Management, Lagos: El-Toda Ventures Limited.

Benemone, E \& Pakepimene, G (2009). The effect of financial management on the modern business organization: A survey of selected firms in Isoko, Delta State.International Journal of Business Common Market Studies, 6(1),208-219

Besson, F.E; Ubana, U.A; \& Udo, D.E (2012). Financial management practices in Cross River State Secondary Schools : Means and methods for attainment of excellence. Journal of Resourcefulness and Distinction, Volume 2(1), 85-86 
Fuchs, C (2010). Collective and State enterprises in agriculture. Management of agricultural,forestry and fisheries enterprise. University of applied sciences, Neubrandenbung,

Germany. Retrieved on 10/9/2012 from http://www.eolss.netyEolss-sampleAllchapter.aspx

Maheshwari, S.N (2011). What is financial management? Retrieved on 11/6/2015 from kalyan-city-biogspot.com/.. What-is -financial management-meaning.htm.

Nchuchuwe, F.F; \& Adejuwon, K.D (2012);. The challenges of agriculture and rural development in Africa: The case of Nigeria. International Journal of Academic Research in Progressive Education and Development. 1( 3), 2226-6348

Nnadi, F.N; Chikaire, J; Echetama, J.A; Ihenacho, R.A; Umunnakwe, P.C \& Utazi, C.O. (2013) Agricultural Insurance: A strategic tool for climate change adaptation in the agricultural sector . Net Journal of Agricultural Science 2(1), $1-9$

Nwoye,M (2008). Economic survey of Nigeria. Aromolaran Publishers, Ibadan.

Ozor,N\& Nnaji C (2010). Difficulties in adaptation to climate change by farmers in Enugu State, Nigeria. Journal of Agricultural Extension.Vol.14(2), December 2010 from https:www.ajol.info>article>download

Sarapaivanich, N (2013). The use of financial information in financial decisions of SMEs in Thailand. Retrieved on 7/8/2014 from http://www.cric.com.au/seasiz/resources /4Sarapaivanich pdf

Singh, P (2011).Fundamentals of financial management, Ane Books Pvt Ltd, New Delhi.

Small and Medium Development Agency of Nigeria (2015). National Policy on Micro, Medium and Medium Enterprises. Retrieved on 6/11/2015 from www.smedan.gov.ng.

Turner,P(2014).Sustainable development. Retrieved on 6/7/2014 from www.uitp.org/public -transport/su stainabl edevelopment

Vitez, O (2013). Definition of financial resources of business. Retrieved March 11, 2013 from http:// www.ehow.com. 